\title{
高強度肌焼鋼の諸特性におよぼす $\mathrm{Pb}$ の影響 について
}

木村篤良*，並木邦夫*，中村貞行*

\section{Influence of Lead on Properties of High Strength Case Hardening Steel}

\author{
Atsuyoshi Kimura, Kunio Namiki and Sadayuki Nakamura
}

\section{Synopsis}

Influence of lead content on the machinability and mechanical properties of high strength case hardening steel which contains $0.5 \%$ of nickel and low silicon was examined. Addition of lead improves the machinability of the steel and the rate is in proportion to the content of lead. Lead has no effect on the fatigue and impact properties when the content is less than $0.042 \%$, but deteriorates them by more addition. The influence of lead on the mechanical properties are discussed based on the size of lead inclusions.

1. 緒論

エンシンの出力上昇や部品の小型, 軽量化にと もない, 浸炭して用いる肌焼鋼について子高強度 化すなわら耐衝撃性及び疲九強さの向上が強く望 まれている。浸炭材の疲れ強さや靬性を改善する ためには, Ni や Mo 含有量の増加と, SやP, Si, $\mathrm{Mn}, \mathrm{Cr}$ 含有量の减少が有効であ ${ }^{1,2)}$, 高強度崡 車用鋼として実用化されている33。

一方, $\mathrm{Ni}$ を添加した高強度鋼は従来の肌焼鋼に 比べて被削性が劣り，切削加工の際に能率の低下 やコストの上昇をむたらすといら久点がある。従 来より，鋼の被削性改善のためにSや $\mathrm{Pb}$ など 快削元素の添加が行われており，肌焼鋼について

1989年 5 月 8 日 受付

"大同特殊鋼侏研究開発本部
も快削鋼が使用されている。これらの元素は鋼中 に非金属あるいは金属介在物として析出して，被 削性を改善するが，同時に亀裂の起点となる可能 性がある。 $\mathrm{Pb}$ の場合, 引張強さが $100 \mathrm{kgf} / \mathrm{mm}^{2}$ 以 下であれば疲れ強さに影響を与えないとされてい る 4.5$\rangle$ 。疲れ限度が約 $80 \mathrm{kgf} / \mathrm{mm}^{2}$ である SCM420 浸炭焼入れ材の回転曲げ試験に打いてる，Pb 含有 量が0.20\%以下であれば疲れ限度に影響しないこ とを確認している6)。しかし，さらに高い疲れ強さ のレベルで, $\mathrm{Pb}$ の影響を論じた報告は見あたらな い。本研究では, 含 $\mathrm{Ni}$ 高強度肌焼鋼の被削性, 疲 れ強さ, 衝撃值におよぼす $\mathrm{Pb}$ 含有量の影響につ いて実験を行い，さらに $\mathrm{Pb}$ 介在物の大きさの影

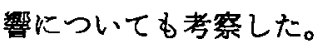

\section{2. 実 験 方 法}

\section{1 試 験 材 料}

試験に用いた材料は， $0.5 \%$ Ni を含有する高 
Table 1. Chemical composition of tested materials. (wt\%)

\begin{tabular}{c|c|c|c|c|c|c|c|c|c|c}
\hline Steel & $\mathrm{C}$ & $\mathrm{Si}$ & $\mathrm{Mn}$ & $\mathrm{P}$ & $\mathrm{S}$ & $\mathrm{Cu}$ & $\mathrm{Ni}$ & $\mathrm{Cr}$ & $\mathrm{Mo}$ & $\mathrm{Pb}$ \\
\hline $\mathrm{A}$ & 0.24 & 0.09 & 0.69 & 0.011 & 0.002 & 0.05 & 0.50 & 1.00 & 0.32 & - \\
\hline $\mathrm{B}$ & 0.25 & 0.08 & 0.70 & 0.010 & 0.002 & 0.02 & 0.48 & 1.00 & 0.32 & 0.017 \\
\hline $\mathrm{C}$ & 0.25 & 0.08 & 0.69 & 0.009 & 0.002 & 0.02 & 0.49 & 0.99 & 0.32 & 0.027 \\
\hline $\mathrm{D}$ & 0.24 & 0.08 & 0.68 & 0.006 & 0.002 & 0.02 & 0.49 & 0.98 & 0.32 & 0.042 \\
\hline $\mathrm{E}$ & 0.24 & 0.07 & 0.69 & 0.010 & 0.002 & 0.02 & 0.50 & 0.99 & 0.32 & 0.047 \\
\hline $\mathrm{F}$ & 0.20 & 0.26 & 0.82 & 0.021 & 0.017 & 0.09 & 0.08 & 1.16 & 0.15 & - \\
\hline
\end{tabular}

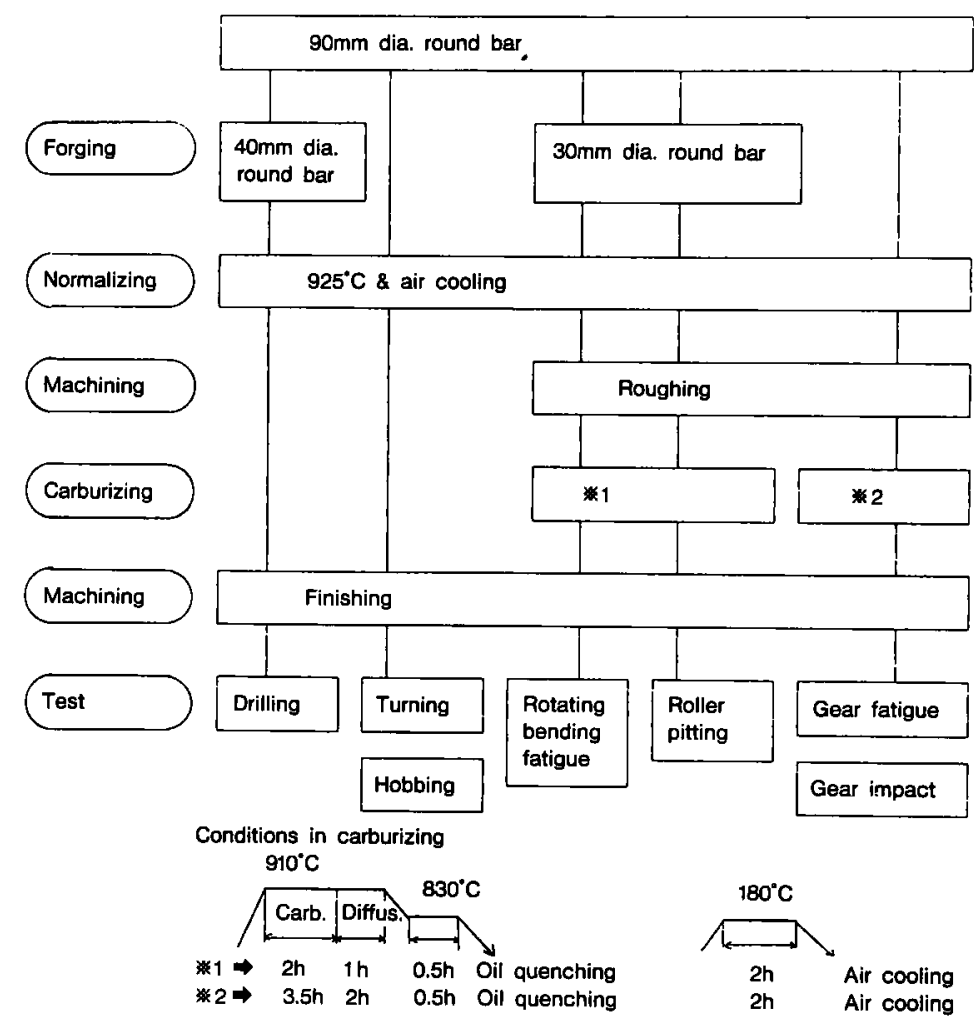

Fig. 1. Processing of tested materials.

強度歯車用の肌焼鋼に0.05\%以下の範囲の $\mathrm{Pb}$ を 添加したものである。Table 1 に試験材料の化学 成分を示す。粒界を脆化する元素である P や非金 属介在物として機械的性質を劣化させる $\mathrm{S}$ ，浸炭 処理時に粒界酸化を助長させる $\mathrm{Si}$ と Mnの含有 量を低くしている。一方, 浸炭部や芯部の鞄性を 改善するために Ni と Mo を添加している。また， 芯部の硬さを確保するためにC 含有量を $0.25 \%$ に
高めている。比較のために SCM420 に相当する鋼 F試験に供した。

これらの材料屾全てアーク炉で溶解し，炬外精 鍊の後 $2.5 \mathrm{t}$ の鋼塊に鋳造した。さらに，熱間圧延 により直径 $90 \mathrm{~mm}$ の丸棒に加工した。この丸棒か ら各種試験片までの加工工程を Fig. 1 にまとめ る。超硬工具による旋削試験とハイスホブによる 茵切り試験は焼ならし処理を実施した $90 \mathrm{~mm} の$ 
Table 2. Cutting conditions in machinability tests.

\begin{tabular}{l|l|l|l}
\hline & \multicolumn{1}{|c|}{ Drilling } & \multicolumn{1}{c}{ Turning } & \multicolumn{1}{c}{ Hobbing } \\
\hline Tool & $\begin{array}{l}\text { HSS SKH51 } \\
5 \mathrm{~mm} \text { dia. }\end{array}$ & $\begin{array}{l}\text { Carbide P10 } \\
-5,-5,5,5,30,0,0.4\end{array}$ & $\begin{array}{l}\text { HSS M34, 92mm dia. } \\
\mathrm{m} 2.5,3 \text { threads }\end{array}$ \\
\hline Feed (mm/rev) & 0.10 & 0.20 & $4 \mathrm{~mm} /$ work rev. \\
\hline Depth of cut $(\mathrm{mm})$ & 20 (blind hole) & 2.0 & - \\
\hline Cutting speed $(\mathrm{m} / \mathrm{min})$ & Variable & 150,200 & 60 \\
\hline Cutting fluid & Non (dry) & Non (dry) & Cutting oil \\
\hline Tool life criterion & Tool failure & $\mathrm{V}_{\mathrm{B}}=0.2 \mathrm{~mm}$ & $\mathrm{~V}_{\mathrm{B}}=0.3 \mathrm{~mm}$ \\
\hline Work size & $\begin{array}{l}90 \mathrm{~mm} \text { dia. } \\
400 \mathrm{~mm} \text { length }\end{array}$ & $\begin{array}{l}40 \mathrm{~mm} \text { dia. } \\
50 \mathrm{~mm} \text { length }\end{array}$ & $\begin{array}{l}31 \text { teeth } \\
82.5 \mathrm{~mm} \text { dia. } \\
200 \mathrm{~mm} \text { length }\end{array}$ \\
\hline
\end{tabular}

王延材を用いた。ハイスドリルによる穴あけ試験 には $40 \mathrm{~mm}$ に鍛造後，焼ならし処理を施した材料 を用いた。回転曲げ疲れ試験とローラピッチング 試験は，压延丸棒を直径 $30 \mathrm{~mm}$ の丸棒に鐉造し， これから試験片を切り出し，浸炭焼入・焼戻し処 理の後，試験に供した。歯車の疲れ試験と衝撃試 験に用いた菊車は，焼ならし処理を施した圧延材 から直接機械加工を行い，浸炭焼入・焼戻し処理 を行った。各試験片の焼ならし処理と浸炭焼入処 理の条件はFig. 1 の中に示した。

\section{2 試 験 条 件}

切削試験における切削条件を Table 2 に示す。 旋削加工寿命試験では，超硬合金 P10 種の工具を 用いて加工を行い,フランク摩耗幅 $0.2 \mathrm{~mm}$ を基準 として工具寿命を求めた。ドリル寿命試験では, ハイスのドリルを用いて穴の加工を行い，工具が 折損または溶損するまでに加工した穴の総深さを 工具寿命值とした。ホブによる雪切り試験では， モジュール2.5の3 条ホブを用い, 横逃げ面の最大 摩耗が $0.3 \mathrm{~mm}$ になるまでに加工した総歯幅と崡 数の積を工具寿命值とした。

回転曲げ疲れ試験は平滑部直径 $8 \mathrm{~mm}$ の小野式 疲㣗試験片を用いて回転数 3500 rpmで実施し た。ローラピッチング試験は直径 $26 \mathrm{~mm}$ の浸炭材 （浸炭まま）を面圧 $375 \mathrm{kgf} / \mathrm{mm}^{2}$ ，滑り率一 $40 \%$, 回転数 $1500 \mathrm{rpm}$ で行った。同一条件で 4 回試験 を実施した。歯車疲れ試験と歯車衝撃試験に用い た試験歯車はモシュール2.5の平齿車であり,雪数 28 と 32 の二種類の歯車を対にして試験を行った。
宷車衝撃試験では衝撃荷重の最大値を求め,これ を5回繰り返した。

直径 $90 \mathrm{~mm}$ の王延材の長手方向に平行に切り 出したサンプルを研磨し，Pb 介在物の分布を測定 した。X線マイクロアナライザを用いて800倍の反 射電子線組成像を撮影し，画像解析装置を用いて 300 個の $\mathrm{Pb}$ 介在物の大きさの分布を調べ，大きさ の代表値として，円相当径を求めた。

\section{3. 結果と考察}

\section{1 被 削 性}

ハイスドリルによる加工における切削速度と工 具寿命の関係を求め, $V_{L=5000}$ ，すなわち工具寿命 が $5000 \mathrm{~mm}$ になる切削速度を計算した。 $V_{L=5} 000$ はドリル加工能率を表す指数となる。 $\mathrm{Pb}$ 含有量と $V_{L=5000}$ の関保を Fig.2 に示す。 $\mathrm{Pb}$ 含有量の増加 に伴い $V_{L=5000}$ が上昇し， $\mathrm{Pb}$ を含有しないA鋼を 基準にすると，0.03\%の $\mathrm{Pb}$ の添加により $V_{L=5} 000$ は約1.3倍に，0.05\%で1.6倍に改善される。同図 に括いて，A鋼は浸宸用鋼として多く使用されて いるF鋼に比べて $V_{L=5000}$ が低いが，これは硬さ が高いことが主たる原因と考えられる。A 鋼に $0.02 \%$ 上上の $\mathrm{Pb}$ を添加することにより，F鋼以 上の水準まで改善される。SCM420鋼の $V_{L=5} 000$ におよばす $\mathrm{Pb}$ 含有量の影響に関して，すでに報 告したが6)，それによると， $\mathrm{Pb}$ 含有量が0.1\%以下 の範囲ではそれ以上の範囲に比べて被削性改善效 果が大きく, $\mathrm{Pb}$ 含有量 $0.08 \%$ て $V_{L=5000}$ は䄪 1.8 倍に上昇し，今回の結果とほぼ対応している。 


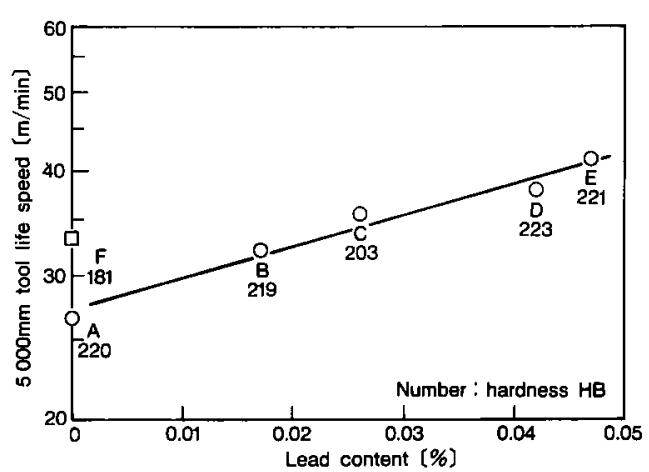

Fig. 2. Influence of lead content on tool life speed in drilling.

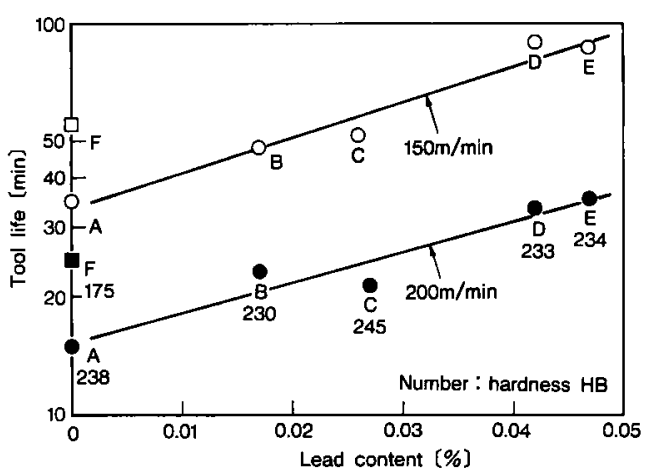

Fig. 3. Influence of lead content on tool life in turning with carbide tool.

超硬工具による旋削加工時の工具寿命之 $\mathrm{Pb}$ 含 有量の関係を Fig. 3 に示す。超硬工具寿命に対す る $\mathrm{Pb}$ の効果は八イスドリルの場合より小さく， 寿命速度で表現できるほどではなく，縦軸に工具 寿命そのものを選んでいる。切削速度 $150 \mathrm{~m} / \mathrm{min}$ と $200 \mathrm{~m} / \mathrm{min}$ の両条件とも $\mathrm{Pb}$ 含有量の増加に伴 い工具寿命が改善され，0.03\%の $\mathrm{Pb}$ の添加によ り約1.7倍に延長される。F鋼に比べると Ni を含 有する $\mathrm{A}$ 鋼は工具寿命が短いが， A鋼に0.03\%以 上の $\mathrm{Pb}$ を添加することにより，A鋼と同等以上 の工具寿命を得ることが可能である。

Fig.4にハイスホブによる歯切り試験における 工具寿命と $\mathrm{Pb}$ 含有量の関保を示す。この場合も， ドリル加工や超硬旋削加工の場合と同様に, $\mathrm{Pb}$ 含 有量の増加に伴い延長される。 $0.03 \%$ のb の添

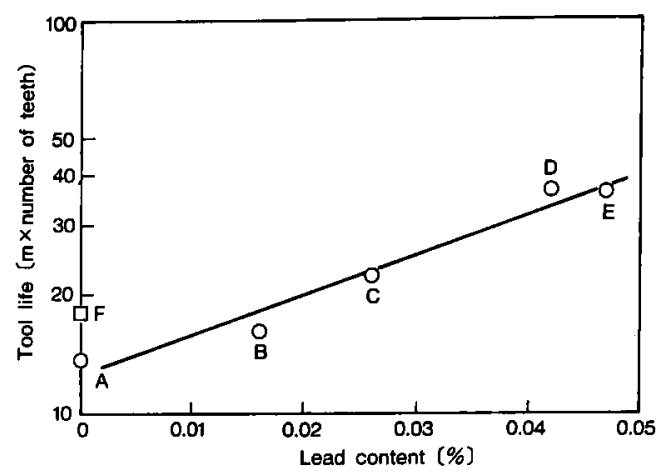

Fig. 4. Influence of lead content on tool life in hobbing.

加による工具寿命の改善は約1.9倍であり，超硬旋 削加工の場合とほぼ一致している。また，徽量の $\mathrm{Pb}$ の添加によって $\mathrm{F}$ 鋼之同等以上の工具寿命か 得られる。

以上のよ5に，A鋼に败量の $\mathrm{Pb}$ を添加するこ とによって, 被削性が改善され，本実験の $\mathrm{Pb}$ 含有 量が0.05\%以下の範团では, 片対数グラフ上で直 線的に向上することが明らかになった。加工様式 によって若干の違いはあるが, $\mathrm{A}$ 鋼に0.03\%の $\mathrm{Pb}$ を添加した鋼は JIS SCM420 鋼 (F鋼) と同等の 被削性を有することが明らかになった。したがっ て, 0.04\%以上の $\mathrm{Pb}$ を添加すれば，F鋼上り優れ た被削性を得ることが可能である。

\section{2 強度}

小野式回転曲げ疲れ試験と㧘車疲れ試験におけ る107疲れ限度と $\mathrm{Pb}$ 含有量の関係を Fig. 5 に示 す。回転曲げと歯車では疲れ限度の絶対值が異な るが，どちらの場合も，Pb 含有量が $0.042 \%$ 以下 の範囲では疲れ限度はほぼ一定であり， $\mathrm{Pb}$ 添加に よる悪影響は現れていない。 $\mathrm{Pb}$ 含有量が $0.047 \%$ のE鋼は疲れ限度が約 $7 \mathrm{kgf} / \mathrm{mm}^{2}$ 低下している。 $\mathrm{A}$ 鋼は $\mathrm{F}$ 鋼に比べて疲れ限度が高く, その差は回 転曲げ疲れ試験の場合で $8 \mathrm{kgf} / \mathrm{mm}^{2}$ ，歯車疲机試 験の場合 14kgf $/ \mathrm{mm}^{2}$ である。したがって,0.042\% 以下の範团であれば，A鋼に $\mathrm{Pb}$ を添加しても疲 れ強さは低下せず，被削性を改善することが可能 である。

従来, SCr420 鋼や SCM420 鋼に $\mathrm{Pb}$ を添加乙 ても，浸炭材の㝿九強さは低下しないと報告され ている6)。しかし，今回の試験の結果では，0:047 


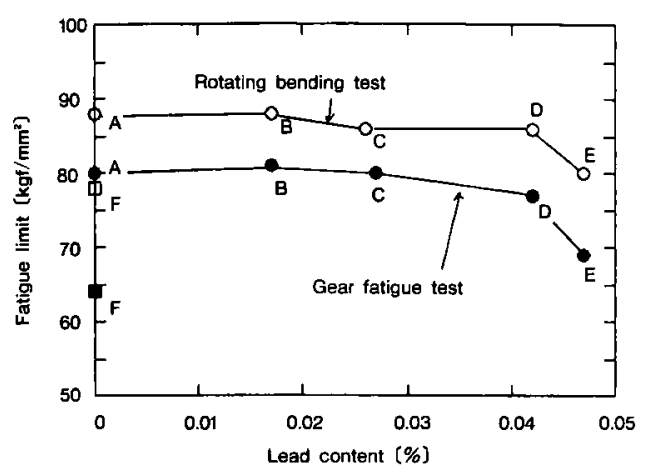

Fig. 5. Influence of lead content on fatigue limit in rotating bending test and gear fatigue test.

\%の $\mathrm{Pb}$ の添加により疲れ限度が低下している。 この原因について考察する。 $\mathrm{SCr} 420$ 鋼や SCM 420 鋼の浸炭処理材には表面に通常 10 $\sim 20 \mu \mathrm{m}$ の粒界酸化層が観察される。この粒界酸 化㒶は $\mathrm{Si} や \mathrm{Mn}, \mathrm{Cr}$ なと酸化物形成元素が多い 汪ど深くなる傾向がある。本実験で用いた $\mathrm{A} 〜 \mathrm{E}$ 鋼はこれらの元素を低くしているので，粒界酸化 深さは約 $5 \mu \mathrm{m}$ であった。粒界酸化は疲れの起点 となるので，粒界酸化層の深さが增加すると疲れ 強さが低下する。また， $\mathrm{A} 〜 \mathrm{E}$ 鋼は $\mathrm{Ni}$ と $\mathrm{Mo}$ をを付 加して浸炭層の破壊䩲性を向上させている。A鋼 がF鋼に比べて疲れ強さが優れているのはこのた めである。一方， $\mathrm{Pb}$ 添加すると金属 $\mathrm{Pb}$ 介在物が 生成寸る。 $\mathrm{B} \sim \mathrm{E}$ 鋼と $\mathrm{SCM} 420$ 鋼に $\mathrm{Pb}$ を $0.09 \%$ と0.20\%添加した材料の $\mathrm{Pb}$ 介在物の大きさを測 定し， $\mathrm{Pb}$ 含有量との関係を Fig. 6 に示した。 300 個の介在物の平均粒径と最大粒径を示している。 どちらす $\mathrm{Pb}$ 含有量が增加すると大きくなる傾向 にある。特に最大粒径は， $\mathrm{Pb}$ 含有量か $0.047 \%$ 以上 で急激に粗大化している。粒界酸化層の深さと比 較すると, SCM 420 鋼の場合, $0.2 \%$ Pb を添加 した材料の $\mathrm{Pb}$ 介在物の最大粒径は $19 \mu \mathrm{m}$ であ り, 粒界酸化層の深さと同程度である。一方, 低 $\mathrm{Si}$ の B — E 鋼の粒界酸化層は約 $5 \mu \mathrm{m}$ であるが, $\mathrm{Pb}$ 含有量が $0.42 \%$ 以下の簌囲では $\mathrm{Pb}$ 介在物の 最大粒径はこれより小さい。 $\mathrm{Pb}$ 介在物む破壊の起 点と成り得るが，その程度が粒界酸化の場合と同 程度であると仮定すると， SCM420 鋼の場合は粒 界酸化層が深く, $\mathrm{Pb}$ を㳢加しても，これより微細

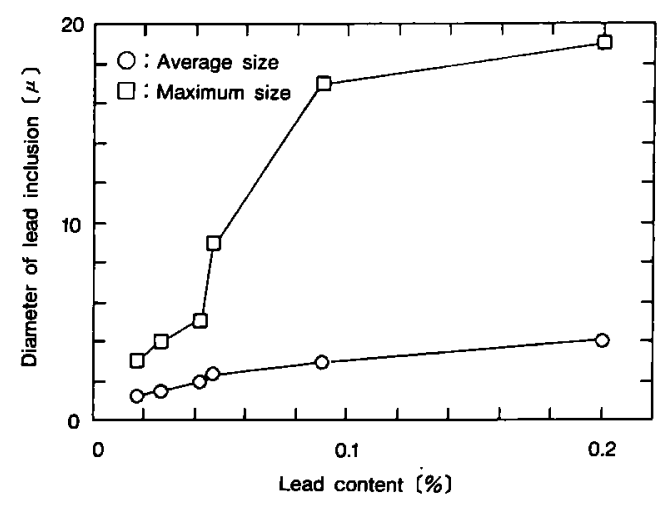

Fig. 6. Influence of lead content on the diameter of lead inclusions.

な介在物になるので，疲れ強さは低下しないるの と考兄られる。一方, 低 $\mathrm{Si}$ 鋼は粒界酸化層が浅く， 疲れ強さが高いが, $\mathrm{Pb}$ を多量に添加すると生成す る $\mathrm{Pb}$ 介在物の大きさが粒界酸化層上りる大きく なり，疲れ強さを低下するるのと考えられる。粒 界酸化層は表面であるか， $\mathrm{Pb}$ 介在物は内部にも存 在する。表層の欠陷と内部の久陥では応力集中に 対する奇与率が異なり，さらに粒界酸化と $\mathrm{Pb} 介$ 在物の亀裂起点としての有害性の程度については 定量的なデータがないので，これ以上の詳細な考 察はできないか，本実験で用いた高強度肌焼鋼の

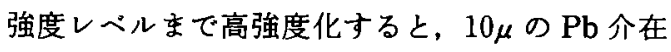
物も亀裂の起点となるものと考光られる。Photo. 1 はE鋼の回転曲げ疲れ試験において, 疲れ限度 の直上の応力で試験した試験片の破面に観察され た亀裂起点の介在物であり， $\mathrm{Pb}$ が測定されてい る。大きさも Fig. 5 の最大粒径に相当しており， 上記の考え方に矛盾のないことを示している。

歯車衛撃試験に打ける衝撃荷重と $\mathrm{Pb}$ 含有量の 関保をFig. 7 に示す。 5 回の試験のデータの範囲 と平均値を示している。A鋼はF鋼に比べて衝撃 荷重が高いが，これは疲れ強さの場合と同様，粒 界酸化層が浅いことと、マトリックスの破壊勒性 が高いためである。A鋼に Pb を添加すると0.042 \%までは衝撃強度を低下しないが, 0.047\%の E 鋼 はわずかに低下している。しかし，疲九強さの場 合にはF鋼に近い水準まで低下するのに対して， 衝揧荷重の場合には F 鋼の 2 倍近い值を維持して いる。E鋼の衝撃強さが低下寸る理由としては疲 


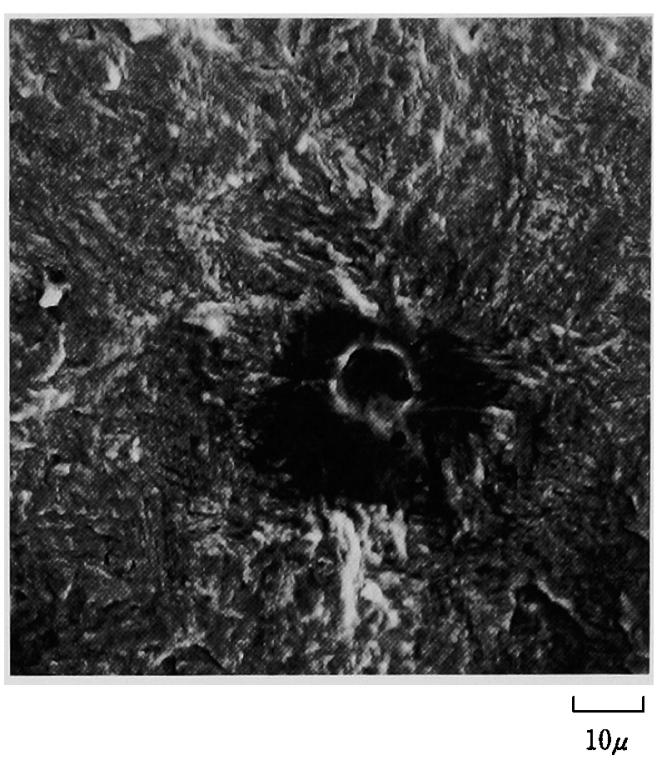

Photo. 1. Lead inclusion at the crack initiation site in rotating bending fatigue test of Steel E.

れ強さの場合と同じものが考えられるが，その程 度が小さいのは, Ni と Moの付加による破壊勒性 改善の効果が $\mathrm{Pb}$ 介在物の悪影響より大きいため であると考えられる。したがって，さらに $\mathrm{Pb}$ 含有 量を増加するとF鋼のレベルまで衝撃強さが低下 する可能性がある。

浸炭材のローラピッチング試験における寿命と $\mathrm{Pb}$ 含有量の関係を Fig. 8 に示す。A 鋼と E 鋼を 比較すると，わずかながらA鋼の方がピッチング 寿命が長い。含有量が $0.047 \%$ 以下の本実験の範囲

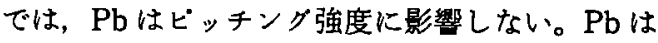
$600 \mathrm{kgf} / \mathrm{mm}^{2}$ といら高面圧下ではビッチング強度 を低下することがよく知られているが6)，本実験 では，375 kgf $/ \mathrm{mm}^{2}$ といら面圧であるために $\mathrm{Pb}$ の影響が忹とんど現れなかったすのと考えられ る。

以上のよ5に, 約 $0.04 \%$ 以下の範囲であれば低 $\mathrm{Si}$ 含 $\mathrm{Ni}$ 系の高強度肌焼鋼に $\mathrm{Pb}$ を添加しても疲 れ強さや衝撃強さ，ピッチンク寿命に影響のない ことが確認された。切削試験の結果と合わせて, 0.03 0.04\%の $\mathrm{Pb}$ を添加した高強度肌焼鋼はく 一ス鋼と同等で，SCM420鋼上り優れた強度と SCM420鋼と同等の被削性を有することが明ら かになった。

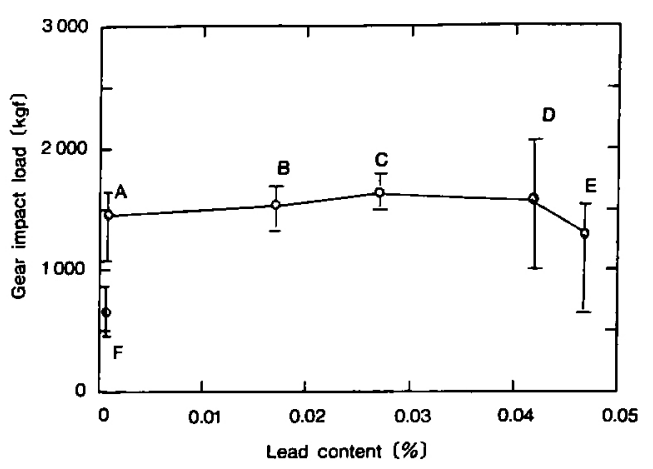

Fig. 7. Influence of lead content on gear impact load.

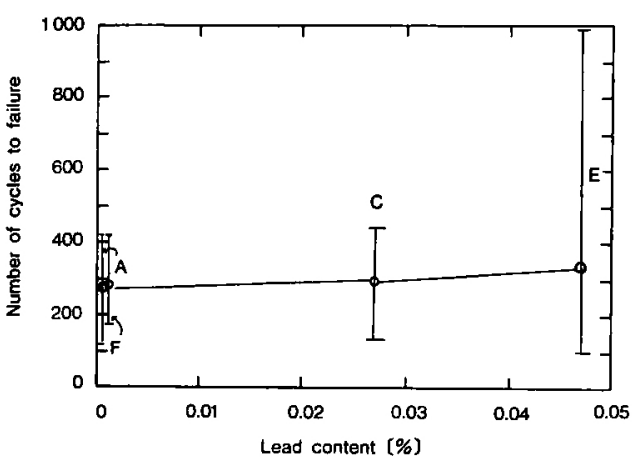

Fig. 8. Influence of lead content on life in roller pitting test.

\section{4. 結論}

浸炭処理による粒界酸化を防止し，破壊靯性を 改善するために, Si と Mn を减少し, Ni と Mo を 增加した高強度肌焟鋼の被削性と強度におょぼす $\mathrm{Pb}$ の影響を試験し，以下の結論を得た。

(1) $\mathrm{Pb}$ 含有量の増加にともない, ハイスドリル 加工性や超硬工具寿命, ハイスホブ寿命は改善さ れる。SCM420 鋼と同等の被削性を得るためには $0.03 \%$ 以上の $\mathrm{Pb}$ を添加することが必要である。

(2) 高強度肌焼鋼に0.042\%以下の範团で $\mathrm{Pb}$ を添加しても，浸炭材の疲れ強さ，衝整強さは低 下しない。これ以上の $\mathrm{Pb}$ を添加すると低下する 傾向が認められる。SCM420 鋼の場合には約 0.2 $\%$ \% 学添加してもこれらの特性は低下しな い。この差は, SCM 420 鋼はすでに破壊の起点と 
なる粒界酸化層が深く, $\mathrm{Pb}$ 介在物の大きさがれ と同等以下であるのに対して，高強度肌焼鋼は粒 界酸化層が浅く，多量の $\mathrm{Pb}$ を添加すると亀裂の 起点となり学る粗大な $\mathrm{Pb}$ 介在物が生成するため であると考えられる。

(3) $\mathrm{Pb}$ を0.03〜0.04\%を添加した高強度肌焼 鋼は SCM420鋼より優れた疲れ強さと衝撃強さ， ピッチング強さなどの強度特性を有すると同時 に, SCM420 鋼と同等の被削性を兼備している。
（文

献)

1）礒川憲二，並木邦夫：電気製鋼，57（1986） 1,4

2）礒川憲二，並木邦夫：電気製鋼，57（1986） 1,13

3）並木邦夫：熱処理, 28 (1988）4，227

4) 浅田千秋, 藤原達雄, 福井彰一：49（1963） 10,1492

5）日本学術振興会製鋼19委員会編：鉄鋼之合金 元素（F），(1966），90，[誠文堂新光社]

6) 木村篤良，中村貞行：電気製鋼，57（1986） 1,51 